\title{
Manipulating Memory and Mourning in Post-socialist Art
}

Abstract: When it comes to global contemporary art practice, the present-day humanitarian discourse abounds in a variety of self-explanatory notions and imperatives such as: political art, community-based art, post-studio practices, participatory art, contextual art, socially engaged art, collaborative art, interactive art. It long ago became apparent that artistic practice can no longer revolve around producing objects for consumption by a passive audience, but must take an active part in interfacing with social reality. In perceiving the modality of a work of art and artistic practice, such a change goes hand in hand with the post-Fordist economic changes and the immaterial and flexible labour imperatives. Claire Bishop has already extensively depicted such artistic phenomena in several of her publications.

Since the early 90s, after the fall of the Iron Curtain in 1989, we have been informed that we ought to be involved with the humanist struggle for the 'politics of human rights', and for 'Art against terrorism', or engaged with social groups and minorities with the aim of integrating them into a 'legal sphere' of life. The humanitarian/humanist imperative, present in everyday political discourse, art and culture, presupposes an opposition between good and evil, where art as a human, humanist and humanitarian activity, is supposed to assume a 'responsible' role. In the view of such rhetoric, Art must be 'political', 'socially engaged' and 'participatory', to the extent that it

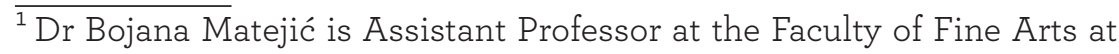
the University of Arts in Belgrade. E-mail: bojanamatejicoo@gmail.com.
} 
indicates the sharp distinction between the places of violence and those of justice. However, as Marx indicated so many times, the division between those who have the right to be seen (the 'polis', or public sphere) and those who do not have a right to a voice (private sphere), assents to social division as such, as well as a rather contingent ethical contraposition between good and evil. Humanitarianism/Humanism in art only affirms the existing democratic phraseology. The humanitarian/humanist regime of art validates a separation between civil society and the abstract society of political equality. Therefore, the aim of this paper is to trace the conceptual distinction between the humanitarian ideology of the current time in the post-socialist context of art and culture, and the thinking and practical application of the concept of the dehumanisation of art.

The manuscript consists of three parts: In the first part, I will recall Adorno's thesis regarding the 'after-Auschwitz' ethic of representation; in the second part, I will discuss the controversy and the implementation of this thesis following $9 / 11$ as related to culture; and finally, in the third part, I will address the issue of how this thesis, as the main current ideological weapon, conditions the contemporary state of affairs in the post-socialist spaces of art and culture, by indicating several key symptoms in artistic production.

Keywords: humanitarianism, humanism, dehumanisation of art, post-socialism, emancipation, 9/11

UDK 7:316.323.6

\section{Manipulacija s spominom in žalovanjem v postsocialistični umetnosti}

Izvleček: Ko govorimo o sodobni globalni umetniški praksi, je današnji humanitarni diskurz poln široke palete samo po sebi razumljivih pojmov in imperativov, kot so: politična umetnost, skupnostno pogojena umetnost, post-studijske prakse, participativna umetnost, 
kontekstualna umetnost, družbeno angažirana umetnost, kolaboracionistična umetnost, interaktivna umetnost. Že dolgo nazaj je postalo očitno, da se umetniška praksa ne more več vrteti okoli produciranja predmetov za potrošnjo s strani pasivne publike, ampak mora zavzeti aktivno vlogo pri povezavi z družbeno realnostjo. Pri dojemanju modalitete umetniškega dela in umetniške prakse gre takšna sprememba $\mathrm{z}$ roko $\mathrm{v}$ roki s post-Fordovskimi gospodarskimi spremembami in nematerialnimi ter fleksibilnimi delavskimi imperativi. Claire Bishop je ta umetniški fenomen izčrpno prikazala že v svojih številnih objavah.

Že vse od zgodnjih 9o. let prejšnjega stoletja, po padcu železne zavese leta 1989, smo obveščeni, da bi morali biti vključeni v humanistični boj za 'politiko človekovih pravic' in v 'Umetnost proti terorizmu', ali pa angažirani v družbenih skupinah in manjšinah s ciljem integrirati jih v 'pravno sfero' življenja. Humanitarni/humanistični imperativ, prisoten v vsakodnevnem političnem diskurzu, umetnosti in kulturi, predvideva opozicijo dobrega in slabega, kjer naj bi umetnost kot človeška, humanistična in humanitarna dejavnost prevzela 'odgovorno' vlogo. S takšno retoriko v mislih mora biti Umetnost 'politična', 'družbeno angažirana' in 'participativna', vse do te mere, da nakazuje strogo razliko med prostori nasilja in tistimi pravice. Vendar pa, kot je tolikokrat nakazal Marx, razlika med tistimi, ki imajo pravico biti videni ('polis' ali javna sfera), in tistimi, ki nimajo pravice do glasu (zasebna sfera), pristaja na družbeno delitev kot takšno, pa tudi na dokaj odvisno etično nasprotje med dobrim in zlim. Humanitarizem/humanizem v umetnosti zgolj potrjuje obstoječo demokratično frazeologijo. Humanitarni/humanistični režim umetnosti potrjuje ločevanje med civilno družbo in abstraktno družbo politične enakosti. Tako je cilj tega prispevka slediti konceptualni razliki med humanitarno ideologijo trenutnega časa v post-socialističnem kontekstu umet- 
nosti in kulture, pa tudi miselna in praktična aplikacija koncepta dehumanizacije umetnosti.

Članek sestavljajo trije deli: $v$ prvem delu se avtorica spomni Adornove teze o 'post-Auschwitz' etiki zastopanja; v drugem delu bo govora o kontroverznosti in implementaciji te teze po 11. septembru v povezavi s kulturo; na koncu pa v tretjem delu naslavlja problematiko kako ta teza, kot trenutno glavno ideološko orožje, pogojuje sedanje stanje $\mathrm{v}$ post-socialističnih prostorih umetnosti in kulture s tem, da bo nakazala več ključnih simptomov v umetniški produkciji. Ključne besede: humanitarizen, humanizem, dehumanizacija umetnosti, postsocializem, emancipacija, 11. september

\section{* * *}

\section{Introduction}

It has been twenty-seven years since the Fall of the Iron Curtain and the promise of a new global post-political, post-ideological and post-historical democratic era. Immediately after this historical moment, politics, art and culture in the Yugoslav context entered the final stage of their disintegration, and instead of the former socialdemocratic ideals of equality, fraternity and unity, there emerged various nationalist imperatives and programmes under the umbrella of 'Western liberal democracy'.

During the 9os, it seemed that avant-gardes in the (post-)socialist Yugoslav spaces of art and culture were not dead: there appeared various alternative, activist, dissident cultural movements (although most of them were financed by cultural initiatives such as the Soros Foundation) $)^{2}$, which strived to overcome the artistic,

$\overline{2}$ Šuvaković, 2002. 
traditional, modernist, projective and utopian avant-garde's endeavours. As a matter of fact, scrutiny of the modernist avantgarde legitimacy commenced long before Yugoslavia collapsed into its political and territorial disintegration: Between the early 70 s and the 90s, some artistic practices such as Slovenian Neue Slowenische Kunst (NSK) and Laibachkunst announced the deconstruction of state socialism and its transition into post-socialism on the ground of the avant-garde legacy. ${ }^{3}$ Net.art also marked the two-fold property of access to technology such as (a)politicality of the internet, making political statements and gestures whose goals were to attack norms of the (traditional) art establishment. ${ }^{4}$ With the postmodernist turn and the collapse of the Eastern bloc, many artists in Eastern and South-Eastern Europe addressed political issues regarding otherness from the feminist, queer and postcolonial identity platforms.

What is most striking when it comes to 'political' or the so-called 'socially engaged art practises' in the last fifteen years, that I find extremely symptomatic in the post-socialist spaces of art and culture, and which, in my opinion, have contributed to the neoliberal globalising cultural industry-is an increasing focus on humanist/humanitarian imperative of memory production and reception. It may seem that many preoccupations of artists who work with memory, nostalgia, Holocaust and specifically with Yugo-nostalgia, were to be carried forward to the critique of the fascist logic that has been survived and has been always (more or less) alive in the contemporary consumer capitalist societies. However, what this kind of art produces is something quite opposite. In the majority of the artistic works of memory, trauma, nostalgia and reconciliation, an accent

\footnotetext{
$\overline{3}$ Erjavec, 2005, 7.

${ }^{4}$ Greene, 2004, 52.
} 
has been placed on the "data(base) aesthetics' ${ }^{5}$ and archival artistic procedures from the moralising standpoint(s) that suffers from the lack of serious research background and query.

On the one hand, the opening towards new technologies (ITC), and, on the other hand bloody wars and political conflicts from the early 9os, enabled the artistic context of South-Eastern Europe to become exquisitely the place of the postcolonial exoticisation, in which the art of memory, trauma and nostalgia with the help of 'memory studies' as its main theoretical point of departure and advocation, have played a significant role. As Norman Finkelstein noted, "The Holocaust has become "an indispensable ideological weapon" in contemporary politics, art, and culture at large, that justifies and acknowledges a doxa according to which 'there is no alternative', and (what is most formidable) the procedure of victimisation of specific, minor group of people (in the USA particularly) - by which certain privileging social relations and forces of production, as well as their political pretensions - gain immunity to criticism. In the wake of Novicks's research, Finkelstein aimed his analysis at the properties and inflections of the so-called 'Holocaust-industry' claiming that, currently all the rage in the ivory tower, 'memory' is surely the most impoverished concept to come down the academic pike in a long time (...) Today, all that remains is the bland, depoliticised language of 'concerns' and 'memory'.

This cultural, political and economic phenomenon may be tracked in the case of 'after-Auschwitz' cultural claim and its gradual ideological distortion that became more perceptible after $9 / 11$. In other words, what I am trying to state is that the art of memory, remembrance,

\footnotetext{
${ }^{5}$ Cf. Bulajić, 2007, 3-22. Wilson, 2006.

${ }^{6}$ Finkelstein, 2001, 10.

${ }^{7}$ Ibid.
} 
trauma and nostalgia represents one of the most powerful contemporary political means for protecting and advocating certain class interests on the global level of the all-more social segregation.

\section{A few notes on the 'after-Auschwitz' dictum}

I would like to begin this analysis with some of Adorno's statements regarding the ethic of the impossibility of art after Auschwitz:

1. Cultural criticism finds itself faced with the final stage of the dialectic of culture and barbarism. To write poetry after Auschwitz is barbaric. ${ }^{8}$

2. I do not want to soften my statement that after Auschwitz it is barbaric to go on writing poetry; it expresses, negatively, the impulse that animates committed literature. (...) The excess of real suffering permits no forgetting. ${ }^{9}$

3. It is self-evident that nothing concerning art is self-evident anymore, not its inner life, not its relation to the world, not even its right to exist. ${ }^{10}$

4. The more the emancipation of the subject demolished every idea of a pre-established order conferring meaning, the more dubious the concept of meaning became as the refuge of a fading theology. Even prior to Auschwitz it was an affirmative lie, given historical experience, to ascribe any positive meaning to existence. ${ }^{11}$

5. In silence alone is the name of the catastrophe to be spoken... But laments and complaints [Klage] about this must reflect-in spirit-the fact that laments and complaints themselves are no longer possible. No weeping melts the armour; the only face left is the one whose tears have dried up. This lies at the basis of an

\footnotetext{
${ }^{8}$ Adorno, "Kulturkritik und Gesellschaft"; Adorno, 1981, 34.

${ }^{9}$ Ray, 2005, cit. 65.

${ }^{10}$ Adorno, 2013, 1.

${ }^{11}$ Ibid. 208.
} 
artistic method that is denounced as inhuman by those whose humanity has already become an advertisement for inhumanity, even if they are not aware of it. ${ }^{12}$

6. Perennial suffering has as much right to expression as one who is tortured has to scream; thus it may have been wrong [to have claimed] that after Auschwitz no more poems [kein Gedicht] may be written. ${ }^{13}$

One could say that the common denominator of all these statements rests upon the standpoint according to which Auschwitz was the inexplicable betrayal of a culture's traditional claim to ennoble and improve humanity. In the light of this argument, Adorno advocated the 'double bind' dimension of art towards artistic autonomy, rather than an engaged art which accepts art's instrumentalisation which presupposes both autonomy and the fait social. The concept of the autonomy of art or of the negative representation of Auschwitz in Adorno's position implies, simply speaking, blocking the extraction of any aesthetic pleasure or redemptive meaning. Adorno's ethics of representation - "the case of Auschwitz" - rests upon a resolution of the issue of how we may proceed to live under the existing conditions of social barbarism in which the Enlightenment cultural programme has failed. It would be barbarism after Auschwitz to reach back to these traditional moralistic forms of art, on the one hand, and on the other, to subject artistic practices to the moralistic rhetoric of every-day politics. ${ }^{14}$

In the light of this argument, it is worth mentioning one of Adorno's crucial examples: Schönberg's The Survivors of Warsaw, in relation to which he elucidates the issue on politicality and the

\footnotetext{
12 Ibid.

${ }^{13}$ Adorno, 1966; Adorno, 1995, 355/369.

${ }^{14}$ Ray, 2005, 64.
} 
ethical claims of art after Auschwitz. As an aporia of historical suffering has been aesthetically transformed into a representation, the victims are to be turned into a work of art. With this procedure, the unthinkable becomes thinkable, thereby opening up the possibility of a redeeming transfiguration. ${ }^{15}$

What it seems that Adorno tries to uphold is the thesis according to which committed art approaches the social aporia too directly, producing positive - I would say, humanist/humanitarian and moral - significations.

\section{The 'After-Auschwitz' ethical claim and its implications in contemporary art after $9 / 11$}

Today one may witness the presence of the 'after-Auschwitz' ethic's claim on contemporary political art in a rather controversial manner, especially to the extent it coincides with the recent historical crisis following the demolition of the Iron Curtain, such as the September 11 attacks in 2001 (9/11). In the early 90s, it became apparent that the 'after-Auschwitz' ethic had come to dominance and was being gradually conventionalised. As a matter of fact, it seems that the 'after-Auschwitz' ethic of representation has been misinterpreted as a consequence of the transitional historical conjunctures and of the conditions of justification for the current democratic phraseology. Deviation of the 'after-Auschwitz' standpoint goes hand in hand with the weakening of the utopian social movements in major Western countries and replacing the social struggles for real democracy with the rules of the State of the Right. The result of such procedure became obvious in the light of an argument which Rancière has already provided: the political has been withdrawn from the public sphere in such manner that it has become indistinguishable from

${ }^{15}$ Ibid. 
the (international) Law. ${ }^{16}$ At the core of the consensual harmony of 'humanitarian discourse (of art)' is the procedure of blurring the boundaries between the factual dispositive (status quo) of the given society and its normative and legislative underpinning. Subsequently, this procedure produces a 'reminder'-a multitude of individuals that fall outside of "this happy circle of fact and law". ${ }^{17}$

The result is obvious: Each otherness deserves to be politically seen and heard. Every minority should have the merit of being included into the social regime of the visible - into the sphere of the 'right to existence'. The manifestness of bodies and their desiring and machinic life ought to be tracked and performed. Artists "cannot write poetry", because, after 9/11, "writing poetry is barbaric". The 'barbaric communism' of Cold War rhetoric has now been replaced with 'Islamic terrorism', justifying the humanitarian right to intervention. 'We' should all 'enunciate', 'declare', 'verbalise', 'speak', 'break silence'... about the Holocaust/Shoah, for such a Thing 'will never happen again' as long as the contemptuously paternalistic military intervention against the disobedient easterners proceeds.

One is not faced here only with the established conventions of socalled 'Holocaust Art', but with the ideological nucleus that pertains to the contemporary demand for art's political, moral commitment and its humanitarian and humanist discourse. Gene Ray well noted that:

...although the limits Adorno imposed were a critical response to new historical conditions after 1945, the rigidification of those limits into a set of blindly followed formulas obscures their own historical specificity and makes it more difficult to test them against the shifting realities of new contemporary conditions. ${ }^{18}$

\footnotetext{
${ }^{16}$ Rancière, 2010, 101.

${ }^{17}$ Ibid. 102.

${ }^{18}$ Ray, 2005, 68.
} 
The 'after-Auschwitz' ethic of representation has, in the process of its reception, undergone ideological transformation when compared to its original formulation. The fear of the 'concentration camp' has proven to be one of the most efficient ideological weapons of contemporaneity. The survival of the fascist logic in consumer capitalism is to be found in the current representational taboos, moralistic imagery and humanitarian and humanist visual rhetoric. The dominance of the 'after-Auschwitz' dictum goes hand in hand with the US-led "War on Terror" and the reinforcement of the Israeli-Palestinian conflict just after 9/11-after 'We' were all informed that we should be struggling against Islamic terrorism. The word 'terrorist' has gradually become an inherently propagandistic term in the everyday political speech that pertains to traditional Enlightenment moralist formalism.

By establishing the place of the so-called 'Terror', the proponents of the current democratic phraseology lay claim to a humanitarian/humanist and moralist discourse of culture, which reflects itself in the soft totalitarianism of the mass consumer democratic societies and the global government of capital. The humanitarian/humanist logic of art justifies the current positive idea of humanity, that is to say, of 'human rights', which stands in accord with the Law that regulates judgements and opinions concerning the Evil that happens in some variable elsewhere. As Badiou maintained:

Ethics is thus part of what prohibits any idea, any coherent project of thought, settling instead for overlaying unthought and anonymous situations with mere humanitarian prattle $(. . .)^{19}$

The current humanitarian/humanist ethical consensus, for which 'after-Auschwitz' rhetoric stands, has been founded on the a

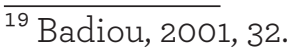


priori recognition and determination of the Evil, and aims at the mobilisation of people, opinion and cultural practices around a positive idea of the Good. The "after-Auschwitz" ethical claim in the much changed circumstances after $9 / 11$ reduces ethical issues to the self-evident principles of human rights and humanitarian actions. Such transformation and misinterpretation of Adorno's 'afterAuschwitz' dictum leads to the definition of (wo)man as victim. Respectively, in the contemporary global cultural circumstances, the artistic ideological principle is reflected in the imperatives of representation of the absolute victim of infinite Evil, which obliges infinite retribution. Ethics, thus, has become a means to identify and conceive of infinite Evil, laying claim to the constitution of an absolute, extra-juridical right to the victim. Two main nucleuses around which this dispositive knits the contemporary ideological marvellous web are 1) The ideal of Good which eliminates political dispute by blurring the boundaries between right and fact (of ways of being and values); 2) Absolute Evil that requires the imperative of representing a (wo)man as a victim.

\section{The case of the post-socialist art world}

In the post-socialist spaces of art and culture, such an ethic can be recognised, especially to the extent that the historical promise of socialism in the last two decades of the $20^{\text {th }}$ century proved to be a failure. Although the term 'postsocialism' in art, generally speaking, refers to the common conditions of late socialism or postsocialism which shaped artistic practices from the early 70s, early or late $80 \mathrm{~s}$ and early $90 \mathrm{~s}^{20}$, I use this term more broadly, which is to say, in order to mark the political, social and economic circumstances of the global neoliberal restoration of the class system and traditional

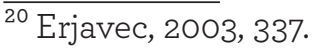


values of the former socialist countries that influenced the shaping of artistic production. ${ }^{21}$ The term 'post-socialist' in my own nomenclature also refers to the process of specific contextualisation, fetishisation and political exoticising of the cultural production in the "barbaric" and "traumatised" political geographies of the former socialist and communist countries. It functions as a convenient label for the "specific" contemporary artistic practices, that have been recognised by the rules and regulations of the contemporary global market economy as something "naturally" inherent to the presupposed political geography.

The 'after Auschwitz' ethical consensus in the post-socialist spaces of art and culture is rooted in the sophistry according to which every revolutionary project necessarily turns into a totalitarian nightmare. 'We' have been convinced over the last fifteen years that every attempt to inscribe an idea of justice and equality turns into Evil. The ethical demand is clear: 'communicate', 'politicise', 'make visible', 'verbalise', 'participate'... - the sharp distinction between the places of violence and those of justice must be verified. From the early 9os,"we' were all to break silence about the crimes in the Balkans and make otherness visible-which, under this supposition, had not been granted the right to any kind of an existence under the previous totalitarian regime. According to such a claim, all true emancipatory art must be "politically" and "ethically" engaged.

The moral, humanitarian nexus of the majority of such practices is based on the afore-mentioned ethical humanitarian dictum at the

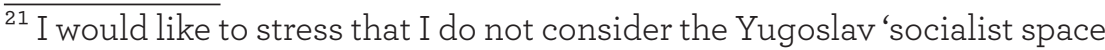
of art and culture' as an innocent area of that what was or should be the righteous and justifiable opponent to the Western capitalist consumerism in any mean possible. When it comes to Yugoslavia, the ideals of the selfmanagement market system failed, and the result was a consolidation of the so-called 'economic statism'.
} 
intersection with the local narrative of the given political geography. As I have pointed out elsewhere ${ }^{22}$, in the contemporary postsocialist constellation of art, which nevertheless assigns to itself the attribute of political emancipation, one can recognise mutually related, key moments:

\section{Fetishisation of art of memory, trauma and nostalgia}

The concept of the art of memory, trauma and of nostalgia inclines to that which is today, in a most popular manner, termed the 'culture of remembrance'. This specific artistic activity mostly takes the form of recycling the existing texts and data from the field of broader culture in the manner of postmodern pastiche. Collecting, appropriating, getting, retrieving, finding of data, information, and cultural texts in the broader sense of the term, appears to be a self-sufficient play with historical illusions. Practices of this kind are structured around certain historical, cultural and aesthetical patterns, myths and stereotypes linked to the past, that stipulate the postcolonial exoticising of the (post-)socialist spaces of art and culture.

The issue of nostalgia was problematised even twenty-five years earlier in the context of the cultural production conditioned by 'late capitalism'. Fredric Jameson, an emblematic figure on the Marxist theoretical polygon, provided an elusive account on this matter. Jameson made his critique of the postmodernist logic, especially when discussing nostalgia film (la mode rétro), claiming that the imperative of nostalgia in the postmodernist cultural production

\footnotetext{
${ }^{22}$ Matejić, 2014, 42-56. In this manuscript, I introduced the broader typology of artistic practices in the post-socialist spaces of art and culture that contribute to the reproduction of the existing power relations. The focus of my attention here is only a memory discourse of art and culture and its humanitarian/humanist logic.
} 
implies "a depersonalised visual curiosity" ${ }^{23}$ in which "intertextuality" is applied as

a deliberate, built-in feature of the aesthetic effect and as the operator of a new connotation of "pastness" and pseudohistorical depth, in which the history of aesthetic styles displaces "real" history. $^{24}$

A memory, as a set of imagery constructions of the past or historical ruptures/traumas, and nostalgia in the postmodern logic of the cultural production, whose logical deviations are still present today, colonises the "present", by which historicism appears as a substitute for "real" history.

Notwithstanding, Linda Hutcheon elaborated a different account on the politics of postmodernism as related to nostalgia / remembering, addressing the issue of the constant critique of the postmodernist ahistoricim. She stated that most of these critiques of the postmodernist nostalgia were focused on the postmodernist "naive" and "nostalgic" recycling of history. In Hutcheon's perspective, what appears to be naive is the unquestionable belief that any recall of the past must, by definition, be sentimental nostalgia. Postmodernist usage of the past, says Hutcheon, does not include the mechanisms of quotation of history with the aim of the transcendental utopian projecting it into future. According to such claim, it might be said that the traces of the postmodernist nostalgia in the contemporary post-socialist spaces of art and culture do not imply a search for transcendent timeless meaning, yet rather an evocation of "a dialogue with the past in the light of the present". ${ }^{25}$

\footnotetext{
${ }^{23}$ Jameson, 1991, xvi.

${ }^{24}$ Ibid., 19.

${ }^{25}$ Hutcheon, 2003, 19.
} 
What I am trying to indicate here by juxtaposing two opposing discourses on postmodernist logic is that 'postmodernist art', in such explanation-that I share with Hutcheon to some extentwields its subversive dimension in its specific historical and geopolitical constellation(s). However, most of the postmodernist tactics are to be soon appropriated by the contemporary global power relations becoming a mainstream. What is most exploited today from the postmodernist strategies are artistic formal procedures such as appropriation, citation, nostalgia (howbeit, here "bad" nostalgia) and memory.

Taking into account this difference, by the memory discourse of the post-socialist art and culture I do not presuppose the postmodernist post-avant-garde / retro-avant-garde, or the post-Soviet anachronic painting etc. which problematise and deconstruct the great historical metanarratives in accordance with the postmodernist logic and cease to announce the political riots and conflicts immediately around the Fall of the Iron Curtain. By the memory discourse of the post-socialist art and culture, I imply the relatively recent symptomatic phenomenon that appeared in the work of the (predominantly) younger generation of artist and art theorists of addressing topics such as the communist and socialist past, the repercussions of the wars in the Balkans, partisan legacy, transformation of urban life in the changed political and economic circumstances after 1989 from the moralising, humanist and memory discourse's standpoints.

Let me dwell more on this problematic. The memory discourse includes a broad corpus of texts and things-from the (contemporary) museum procedures and regulations of collecting, archiving, managing, allocating, representing and distributing of knowledge (as the 'legal' battle over repressed memory) to the market for cultural production, artistic works, academic books and articles that 
refer to memory as key word-that all together create and participate in the so-called 'memory industry'. ${ }^{26}$ The academic interest and fascination with the memory discourse is a quite new phenomenon. The concept of 'collective memory' appeared as an object of scholarly enquiry in the early twentieth century with the first serious 'crisis of historicism'.

The term "collective memory" in the 'culture of remembrance' nomenclature was first used by Hugo Hofmannsthal, while Maurice Halbwachs regards memory, contrary to H. Bergson and S. Freud, as a specifically social phenomenon in his book The Social Framework of Memory (1925). However, what is most striking is that the academic and cultural interest in memory studies has grown with the postmodernist dominance in the 80s, especially with the emergence of two books: Yosef Yerushalmi's Zakohor: Jewish History and Jewish Memory (1982) and Pierre Nora's "Between Memory and History" the introduction to an anthology Lieux de mémoire (1984). In these manuscripts, memory is regarded as a "primitive or sacred form of accessing the past that is opposed to modern historical consciousness". For Yerushalmi, the Jews were the archetypal people of memory who had adopted history only recently and then only in part, for 'modern Jewish historiography can never replace an eroded group memory'. For Nora, memory was an archaic mode of being that had been devastated by rationalisation: 'We speak so much of memory because there is so little of it left". ${ }^{27}$

The logical justification of the indispensable conceptualisation of memory, in the wake of postmodernism -as something that, under the supposition, confronts ('Western') aspiring to metaphysics and historical grand metanarratives-rests upon humanist

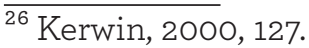

${ }^{27}$ Ibid.
} 
/ human and moralising belief that the process of 'memorising' will necessarily prevent from the (radical) Evil / Holocaust (to ever happen again). All the more, some proponents believe that the 'memory discourse' has a political dimension to the extent it takes a critical stance towards the fascist consumer logic of (contemporary) capitalism. Unfortunately, to recall briefly Hannah Arendt's seminal manuscript, a (radical) Evil has nothing to do with the exception of sadism, perversity, totalitarianism, community, brotherhood, solidarity, unity, socialism, communism, partisans, capitalism, history, metaphysics (whatever word or label used), yet with the humanist, moralising "terrifying normality" as such. ${ }^{28}$ Right here, one may remark all the fine curtains of the humanitarian/humanist ideological anamorphosis of the 'after-Auschwitz' ethical dictum.

During the gos in the post-Yugoslav spaces of art and culturesocialism, communism, socialist modernism, self-management, partisan legacy etc. appeared to be indecent words. Only after the beginning of new century, the memory discourse-which includes artistic imagery reinvention of the traces of either the "barbaric" and/or "golden era" of the communist/socialist past, as well as the implications of the process of vanishing of the socialist/communist culture under the changed socio-political and economic circumstances-was enabled to be brought into light. As it was assured that (state) communism/socialism (both in political life and culture) would not survive, that it was completely defunct and that it no longer represented a threat to the neoliberal democratic ideals, the memory discourse of the post-Yugoslav / post-socialist (or of the recuperations of the war) cultural production was finally "allowed" to exist, only if it is to be exploited by the new imperial regimes of power.

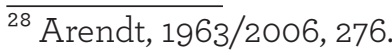


Consider some of the examples of the (particularly) younger generations of artists: Relying on some visual patterns of (post-)conceptual art, Vladimir Milanović-the author of the exhibition Invisible violence (2014) at the Museum of Contemporary Art in Belgrade, declaratively addresses the issues of the post-war trauma of the former Yugoslav societies, as well as the questions of how the media and the institutions in the post-Yugoslav societies "create public sphere" and "collective memory". ${ }^{29}$ This project, to some extent, stems from the broader project "Četiri lica Omarske" initiated by artist Milica Tomić. The exhibition launches an avalanche of serious questions: from the visual aspects and methodology of the work as related to its conceptual principles and the framework to the moralising standpoint typical for the humanitarian/humanist discourse. Among many, one imperative is imposed: We are all obliged to speak, enunciate, declare, make visible, face etc. "our/Serbian/German... guilt" for the Terror. Take another "young” example-Benjocki's sound installation made of recordings and archival material of the International Criminal Tribunal for the former Yugoslavia (ICTY) titled Soundtrack (Statements of Guilt) exhibited at the Royal Academy of Arts in the Hague in 2011. The author produced a piece of music from the previously archived, recorded, transcribed and translated voices and statements of guilt. The work addresses the "reciprocal alienation of voice and body from words and their context, and their complex relationship with to how the trauma experienced in the countries of the former Yugoslavia and the Netherlands is articulated." 30 These works of art rather exemplify that of what Benjamin called $a(n)$ aestheticisation of politics ${ }^{31}$ of the existing humanitarian

\footnotetext{
${ }^{29} \mathrm{Cf}$. http://vladimirmiladinovic.blogspot.rs/.

${ }^{30} \mathrm{Cf}$. http://www.kristinabenjocki.com/soundtrack-statements-guilt.

${ }^{31}$ Benjamin, 2008, 41. Cf. Martin, 1992, 21.
} 
democratic materialism ${ }^{32}$ / 'after-Auschwitz' ethical demand. The aesthetical conception of memorising, remembrance and personal enunciation here stand for the process of "normalising" of something which can never be symbolised-something which is at the core of the "normality" per se.

\section{An artistic act of mourning}

The second symptom that I find dominant in the last fifteen years in the work of a younger generation of artist / theorist is an artistic act of mourning.

The concept of an artistic act of mourning implies artistic practices that address the exotic mourning of the vanishing of the socialist and communist aesthetic and historical legacies, such as partisan history and the collapse and/or lost utopia (dystopia). More precisely, the act of mourning in art privileges lost object of desire which had implied some social values in the former socialist and communist countries. What it seems here is the major focus of the issue, is, actually, the act of mourning for the loss of the emancipatory projective object of the great modernist utopias-which testified to even before Auschwitz. ${ }^{33}$ Yet, that of what is missing is nothing other than the "memory of deep memory".

What is enacted is nostalgia for nostalgia, for the grand older extinct questions of origin and telos, of deep time and the Freudian Unconscious (...) for the dialectic also, as well as all the monumental forms left high and dry by the ebb tide of the modern moment, forms whose Absolutes are no longer audible to us, illegible hieroglyphs of the demiurgic within the technocratic world. ${ }^{34}$

\footnotetext{
$\overline{32}$ Badiou, 2016.

${ }^{33}$ Horkheimer, Adorno, 2006.

${ }^{34}$ Jameson, 1991, 155.
} 
One should take into consideration, as Domenic Boyer stated, that the nostalgia production is never neutral or innocent when considering the system and categories of valuation. Similar to history construction, it is a narrative which is selected however legitimised, since it comes "from above" (personal/social vs. history/state). Furthermore, one should not neglect a discrepancy between the 'industry of nostalgia' and the 'culture of nostalgia' as remarks Mitja Velikonja, since the former implies the exploitation of the culture whose main resources are sentiments and emotions. ${ }^{35}$

Let me take an example: Tanja Deman's and Vesna Jovanović's collaborative project Deserted Utopia (artist book, 2010) reflects on examples in architecture and urban planning whose utopian "goal" was emancipation of the modern Yugoslav society in the light of aspiring to social values of 'unity', community etc., as that which today represents a sign of a vanishing (either "golden" or "shameful") socialist past. Similar Yugo-nostalgic reflections and outcomes are suggested in Marta Popivoda's film How Ideology Moved Our Collective Body-a work in which the author seeks to make (media) information, often lost or displaced, physically present, using the methodology of archival samplings, juxtapositing the media constructions of the life form(s) in the socialist past and the 9os, that marked the collapse of Yugoslavia. Ivan Fijolic cites the visual stereotypes and constructions of the socialist realism in the work NEO N.O.B - The (Un-)popular Culture of Remembrance in the manner of the postmodernist pastiche and transfigures the visual narrative by incorporation of the elements of pop culture. In the installation Here Come the Women (2015) Adela Jusić in collaboration with Andreja Dugandžić produces monumental collages as the citation of the evident visual markers and traces from the media con-

${ }^{35}$ Popović, Belić, 2014, 94, 25. 
structions of the woman's social life under the Yugoslav socialist regime. The installation problematises that of what could/might socialism and/or equality claim mean for the "average" woman. Similar topics and issues are initiated in the work Born without a Reason: The Internal Soliloquy in Personal Encounter with Heroines (2011) by Milica Rakič etc.

Most of these artistic practices, more or less, tend to use 'Yugonostalgia' as the artistic act of mourning aspiring to political and critical reflections on the current crisis of democracy and neoliberalism. Among other aims, they tend to reflect on the object that could/might be realised, but in the end failed. However, what is overseen in this relatively new cultural phenomenon is that they push the contemporary neoliberal commodification of the 'post-socialist context of art' to the extreme, by preserving the position of the object for victimisation, exotification and humanitarian ideological anamorphosis.

\section{Conclusion}

At the end, I must stress that the aim of this manuscript was not to render the listed artistic works as politically insignificant in the current state of the post-socialist art and culture-or worse to claim that such artistic practices should not exist-yet to open a dispute for the identification and critical reflection of the new, quite fashionable tendency of the (younger generation) artist/theorist who comes (geographically) from the post-Yugoslav context. The reasons for this situation should be found in the institutional dispositive (art schools and master programmes) in (Western) Europe that create and shape this global demand on the one hand, and on the other-the global market economy which rests upon the procedures of categorisation, separation and recognition, specifically inherent in the given culture/geopolitics. 
Distortion of the 'after-Auschwitz' ethical dictum especially after 9/11 became one of the most powerful imperative as regards arts and culture in which memory discourse plays the most significant role. The art of memory, trauma and nostalgia contributes to the recent restoration of the classical liberal bourgeois society values (equality, civil rights, free speech, open media, humanitarianism, etc.) resting upon the production of the "degraded repository of images and simulacra" ${ }^{36}$, in such a way that they substitute and reify the stereotypical constructions for filling the gap between reality and the past itself.

Therefore, today inasmuch as, Hanno Rauterberg ${ }^{37}$ says, contemporary art is finally "free" from the categories of the form, technic and visual, perceptible aspects of the modernist achievements, the issue of its function, its forms of political, economic and social "value" / agency, its modes of shaping one's/social life, become more important. In the present dominant humanist/humanitarian circumstances, one should try to think and practically indicate the possibilities of the process of the dehumanisation of art-of the moments of refusal that exceed the current culture's affirmative social functions. As the humanitarian imperative of a/Art calls for obedience to some supposed Good against Evil, for which it is assumed cultural workers must strive, an art that aspires to emancipation might start by recognising the dominant images and spectacularisations of democratic phraseology critically demonstrating this very process of recognition. All these moments of post-socialist artistic practices that I have just identified, more or less acknowledge, fortify and consolidate the current 'fear of Terror' and ideological anamorphosis of the 'after-Auschwitz' ethic of representation.

\footnotetext{
$\overline{{ }^{36} \text { Jameson, } 123 .}$

${ }^{37}$ Rauterberg, 2016, 8.
} 


\section{Bibliography}

ADORNO, T. (1966): Adorno, Negative Dialektik, in Gesammelte Schriften, vol. 6.

ADORNO, T. (1981): "Cultural Criticism and Society," in: Prisms, trans. Samuel and Shierry Weber, MIT Press, MA: Cambridge.

ADORNO, T. (1995): Negative Dialectics, trans. E. B. Ashton, Continuum, New York.

ADORNO, T. (2003): "Kulturkritik und Gesellschaft," in: Gesammelte Schriften, vol. 10.1.

ADORNO, T. (2013): "Art, Society, Aesthetics", in: Aesthetic Theory, Bloomsbury, London - New York.

ARENDT, H. (1963/2006): Eichmann in Jerusalem: A Report on the Banality of Evil, Penguin Books, New York - London -Toronto.

BADIOU, A. (2001): Ethics: An Essay on the Understandnig of Evil (Peter Hallward trans.), Verso, London - New York.

BENJAMIN, W. (2008): The Work of Art in the Age of its Technological Reproducibility and Other Writings on Media, Harvard University Press, London - New York

BULAJIĆ, V. (2007): Database Aesthetics. Art in the Age of the Information Overflow, University of Minnesota Press, London - Minneapolis.

ERJAVEC, A. (2003): Postmodernism and the Postsocialist Condition. Politicized Art under Late Socialism, University of California Press, Berkeley - Los Angeles - London.

ERJAVEC, A., ed. (2005): Aesthetic Revolutions and Twentieth-Century Avant-Garde Movements, Duke University Press, Durham London.

FINKELSTEIN, G. N. (2001): The Holocaust-Industrie: Wie das Leiden der Juden ausgebeutet wird, Piper Verlag, Tübingen.

FOSTER, H. (2004): “An Archival Impulse”, October, 110, 3-22. 
GREENE, R. (2004): “Net. Art”, Internet Art, Thames \& Hudson, London - New York.

HORHEIMER, M., ADORNO, T. (2006): Dialektik der Aufklärung: Philosophische Fragmente, Fischer Taschenbuch Verlag, Frankfurt am Main.

HUTCHEON, L. (2003): A Poetics of Postmodernism. History, Theory, Fiction, London - New York, Routledge.

JAMESON, F. (1991): Postmodernism, Or the Cultural Logic of Late Capitalism, Duke University Press, Durham.

KERWIN, L. K. (2000): "On the Emergence of Memory in Historical Dicourse", Representations, 69, 127-150.

MARTIN, J. (1992): “'The Aesthetic Ideology' as Ideology; Or, What Does It Mean to Aestheticize Politics?”, Cultural Critique, 21, 41-61. MATEJIĆ, B. (2014): "Emancipation, Memory and the Revolutionary Subject of Art”, Život umjetnosti: Magazine for Contemporary Art, 95, 42-56.

POPOVIĆ, M., BELIĆ, P. (2014): “Jugonostalgija: Jugoslavija kao metaprostor u suvremenim umjetničkim praksama”, Život umjetnosti: Magazine for Contemporary Art, 94, 1.

RANCIÈRE, J. (2010): "September 11 and Afterwards. A Rupture in the Symbolic Order?”, in: Rancière, J., Dissensus: On Politics and Aesthetics, Continuum, London - New York, 97-104

RAUTERBERG, H. (2016): Die Kunst und das gute leben. Über die Ethik der Ästhetik, Suhrkamp Verlag, Berlin.

RAY, G. (2005): Terror and the Sublime in Art and Critical Theory. From Auschwitz to Hiroshima to September 11, Palgrave Macmillan, New York.

WILSON, S. (2006): Datasthetics - How To Do Things With Data, Arkzin \& WHW, Frankfurt, Zagreb. 


\section{Webography}

BADIOU, A.: „Bodies, Languages, Truth“ http://www.lacan.com/ badbodies.htm 14. December 2016.

ŠUVAKOVIĆ, M. (2002): "Ideologija izložbe: o ideologijama Manifeste" http://www.ljudmila.org/scca/platforma3/suvakovic.htm 1. December 2016.

http://vladimirmiladinovic.blogspot.rs/ 7. September 2016. http://www.kristinabenjocki.com/soundtrack-statements-guilt 7 . September 2016. 